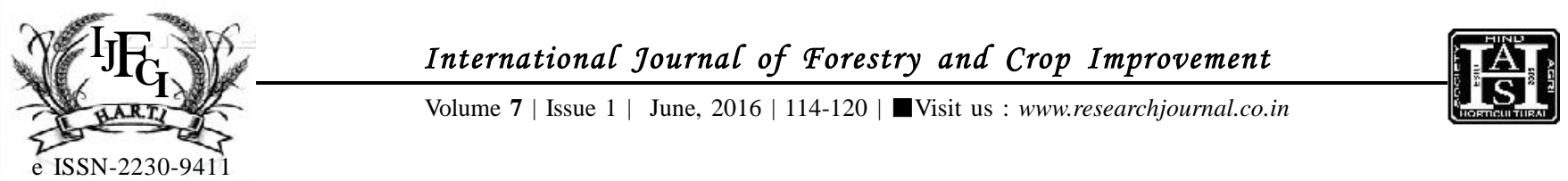

\title{
Characterization of endophytic plant growth promoting traits of Methylobacterium sp. isolated from banana (Musa sp.)
}

\author{
PushPakanth Periyasamy, K. Ilamurugu and M. SenthilKumar
}

\begin{abstract}
A total of 26 endophytic Methylobacterium sp. strains were obtained from surface sterilized leaves of two banana cultivar (Robusta and Nattu poovan) and the strains were tested for its ability to fix atmospheric nitrogen, EPS and IAA production for promoting banana tree growth. The result of the present study demonstrated that endophytic population ranged from 4.03 and $4.14 \mathrm{log}$ cfu per gram of leaf tissue. Among these four isolates were chosen based on colony morphology and their distinct pigmentation. All the selected four isolates were able to grow in nitrogen free methanol mineral salt medium. The synthesis of indole-3-acetic acid (IAA) in the presence of L-tryptophan was detected in all the isolates tested. The isolate FM2 (Methylobacterium sp.) produced the highest amount of IAA $\left(13.01 \mu \mathrm{g} \mathrm{ml}^{-1}\right)$ in medium supplemented with L-tryptophan and was able to synthesize IAA in the absence of L-tryptophan. The maximum amount of ASP and WSP was recorded in FM3 $(21.73 \mu \mathrm{g}$ $\left.\mathrm{ml}^{-1}\right)$ and FM1 $\left(157.79 \mu \mathrm{g} \mathrm{ml}^{-1}\right)$, respectively. They were tentatively identified at species level based on carbon utilization test. The classified strains were also screened for methanol dehydrogenase (mxaF gene sequencing) using specific primers and obtained 555 bp PCR product. So the Methylobacterium sp. strains analyzed here had a promising potential for developing as a plant growth promoting bacteria for sustainable agriculture.
\end{abstract}

KEY WORDS : Musa sp., Nitrogen fixation, Indole-3-acetic acid, Exopolysaccharide, Methylobacterium sp.

How TO CITE THIS ARTICLE : Pushpakanth Periyasamy, Ilamurugu, K. and Senthilkumar, M. (2016). Characterization of endophytic plant growth promoting traits of Methylobacterium sp. isolated from banana (Musa sp.). Internat. J. Forestry \& Crop Improv., 7 (1) : 114-120, DOI: 10.15740/HAS/IJFCI/7.1/114-120.

Article Chronical : Received : 29.01.2016; Revised : 26.04.2016; Accepted : 27.05.2016

\section{MEMBERS OF RESEARCH FORUM}

Address of the Correspondence : PUSHPAKANTH PERIYASAMY, Department of

Agricultural Microbiology, Tamil Nadu Agricultural University, COIMBATORE (T.N.)

INDIA Email : lalitha_pushpakanth@yahoo.com

Address of the Coopted Authors : K. ILAMURUGU AND M. SENTHILKUMAR,

Department of Agricultural Microbiology, Tamil Nadu Agricultural University, COIMBATORE (T.N.) INDIA 